\title{
FLOOD INUNDATION AND HAZARD MAPPING OF RIVER ZUNGUR WATERSHED USING GIS AND HEC-RAS MODELS
}

\author{
A. B. Olasunkanmi ${ }^{1}$ and S. Dan'azumi ${ }^{2, *}$

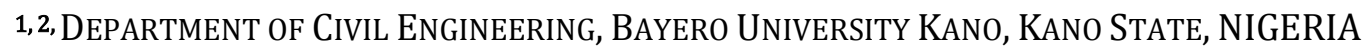 \\ E-mail addresses: 1 aybashir2010@gmail.com, ${ }^{2}$ sdanazumi.civ@buk.edu.ng
}

\begin{abstract}
Zungur watershed located in the southern region of Bauchi State has no record of existing flood plain mapping. This research integrated HEC-RAS with GIS to estimate the flood zone of Zungur Watershed. HEC-GeoRAS, an ArcView GIS extension HEC-RAS, was used to delineate the areas prone to flooding at different discharges of 2 to 100 years return periods. Area inundated by 2, 5, 10, 25, 50 and 100-year floods were 186.71, 189.15, 193.59, 197.63, 200.09 and $205.32 \mathrm{~km}^{2}$ respectively with maximum inundation depths ranging from $5.37 \mathrm{~m}$ to $7.37 \mathrm{~m}$ for 2 to 100 years. Flood inundation mapping showed that Zungur, Dass, Bagel, Sabongida, Mun, Birim, Talagutta and Gwani Settlements are likely to be affected by 100-year flood and agricultural land is the most affected landuse. The result of this study showed that hydraulic simulation and GIS could be effective for floodplain mapping and management.
\end{abstract}

Keywords: River Zungur, Flood Inundation, Frequency analysis, HEC-RAS, GIS.

\section{INTRODUCTION}

Flood represents the most common global hazard causing phenomenal losses. Throughout human history, floods have taken a heavy toll on properties and lives and caused more economic losses than any other hazard [1].The frequency with which flood occur is increasing in many regions of the world [2]. Floods can also be caused by anthropogenic activities and human interventions in the natural processes such as increase in settlement areas and population growth over low lying plains prone to flooding leading to alterations in the natural drainage pattern. In Nigeria, flood displaces more people than any other disaster and about 20 per cent of the Nigerian population is at risk of flooding [3]. Flooding is therefore a perennial problem in Nigeria that consistently causes deaths and displacement of communities. For instance, in 2010, about 1,555 people were killed and 258,000 more were displaced by flooding [4]. In 2012, floods also claimed 361 lives, and displaced 2.1 million people [5]. Bauchi Local Government Area of Bauchi State in Nigeria has recorded series of flooding events in recent times caused by prolonged and heavy rainfall. The southern part experiences more rainfall than the northern part. Most of the rivers in the state are intermittent and only become active in the rainy season causing immense damage. Zungur District in the southern part of Bauchi is drained by River Zungur. The river bank is prone to erosion every year and has been eroding its bank causing severe inundation. In 2012, 2015 and 2016, many settlements, farmlands and properties have been destroyed due to the heavy and prolonged rainfall.

In this regards, structural as well as non-structural counter-measures should be planned and implemented by the government. The delineation of flood extents and depths within the floodplain is essential for flood management [6]. In recent decades, non-structural flood control methods have been noticed as effective and economical methods in decreasing flood effects [7]. Flood inundation and hazard map is one of the nonstructural measures for floodplain management. This non-structural method has less cost compared to structural methods [8].

This research employed ArcGIS and HEC-RAS. HEC-RAS can be used to perform river flood modelling using flood plain encroachment analysis and the results can be presented in a geospatial format [9]. Research on integrating GIS and hydrological models for flood plain mapping has not been carried out in Zungur, thus, the study provide useful suggestions to identify and delineate areas vulnerable to flooding. 


\section{MATERIALS AND METHODS}

\subsection{The Study Area}

River Zungur Watershed originates from Plateau hills in Plateau State and drains towards the southern part of Bauchi State. It extends between latitudes $9^{\circ} 22^{\prime} 00^{\prime \prime}$ and $10^{\circ} 6^{\prime} 50^{\prime \prime}$ north and longitudes $9^{\circ} 6^{\prime} 30^{\prime \prime}$ and $10^{\circ} 3^{\prime} 6^{\prime \prime}$ east, with a watershed area of $8266 \mathrm{~km}^{2}$. The watershed is inhabited by about 105 communities. It is drained by River Zungur with three major tributaries (Mun, Doka and Kumgas) originating from Jos plateau and connecting to River Dindima.

Table 1: River Zungur catchment characteristics

\begin{tabular}{llll}
\hline S/N & Watershed Characteristics & Unit & Result \\
\hline 1 & Area & $\mathrm{km}^{2}$ & 8266 \\
2 & Stream order system & & $5^{\text {th }}$ order \\
3 & Stream density & $\mathrm{km}^{-1}$ & 0.150 \\
4 & Drainage density & $\mathrm{km}^{-1}$ & 0.040 \\
5 & Length of overland flow & $\mathrm{km}$ & 11.360 \\
6 & Form factor & $\mathrm{km}$ & 0.530 \\
7 & Compactness coefficient & & 0.400 \\
8 & Elongation ratio & & 0.690 \\
9 & Circularity ratio & & 0.760 \\
10 & Time of recession & days & 5.000 \\
11 & Basin slope & & 0.0024 \\
12 & Time of concentration & min & 192 \\
\hline
\end{tabular}

The elevation of Zungur Watershed ranges from $463 \mathrm{~m}$ to $1750 \mathrm{~m}$. Floods in the watershed occur during the rainy season (July to September). Rainfall starts around April/May with peaks in August and ends by October.
The average annual rainfall in the watershed is between $840 \mathrm{~mm}$ to $1085 \mathrm{~mm}$. The vegetation in the zone is Sahel and Sudan-Savanna. The basic occupation in Zungur is farming and people grow variety of crops such as maize, rice, beans, groundnut, garden egg, potato, cassava, sweet melon and others. Apart from planting of crops, grazing of cattle is also practiced there. Table 1 shows the watershed characteristics.

\subsection{Rainfall Data}

Daily rainfall data for Bauchi covering a period of 60 years (1949-2009) was collected from Nigeria Meteorological Agency (NIMET). Log Pearson Type III and Gumbel Distributions were employed for flood frequency analysis. The two distributions were subjected to Goodness of Fit Tests using the EasyFit software where the model with the highest rank was used as an input for the HEC-RAS.

\subsection{Digital Elevation Model (DEM) and LandSat Data}

The DEM is the primary data used for topographical analysis. This DEM was therefore converted into Triangular Irregular Network (TIN) which was useful in the generation of geometrical data model in the HECRAS model and for flood hazard map generation. Figure 1 shows the DEM of the study area. $90 \mathrm{~m} \times 90 \mathrm{~m}$ resolution LandSat ETM image for August 2017 was downloaded from United States Geographical Service (USGS) website. This was used to generate the land use land cover classification map of the study area.

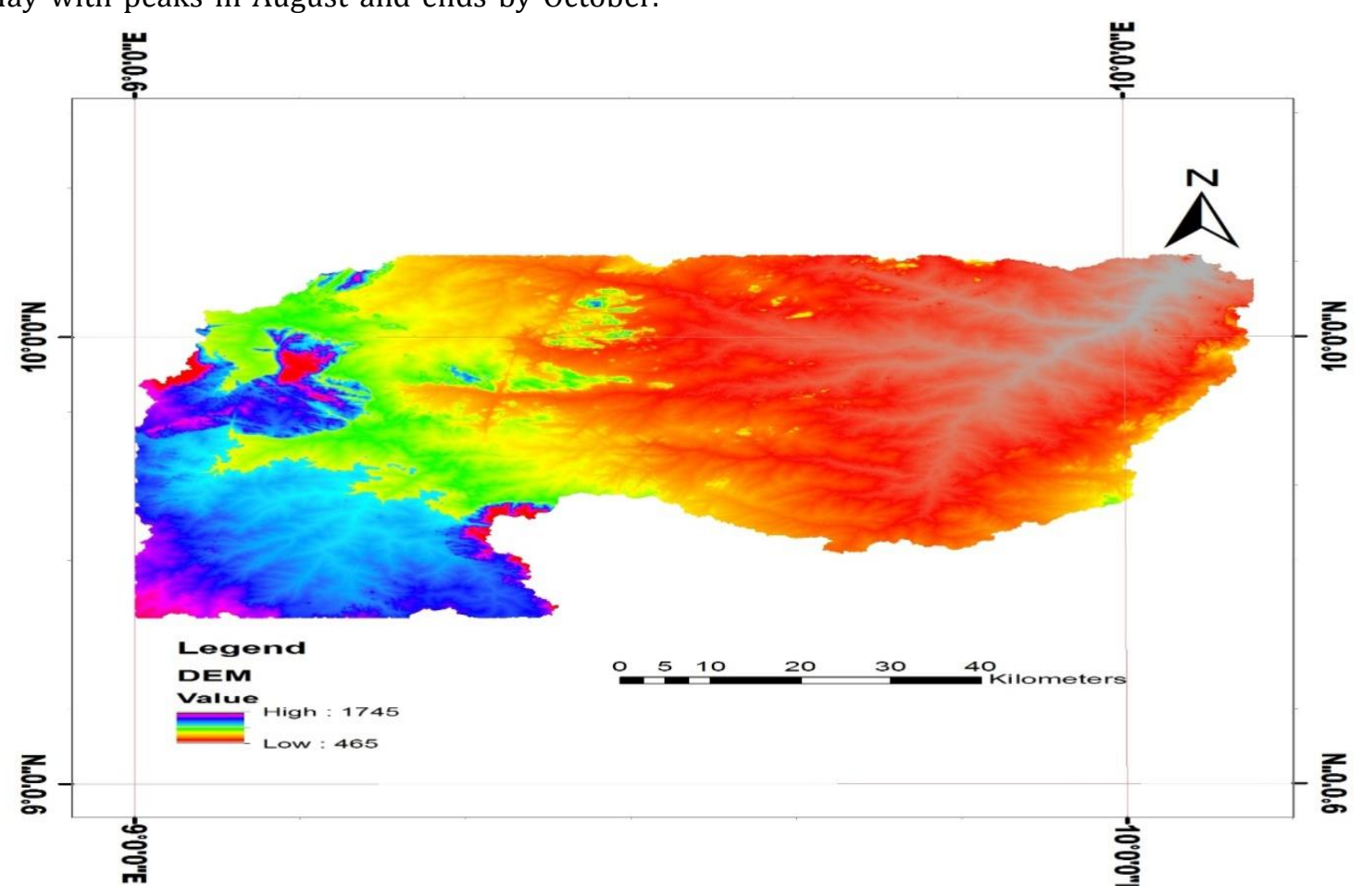

Figure 1: DEM of River Zungur Watershed 


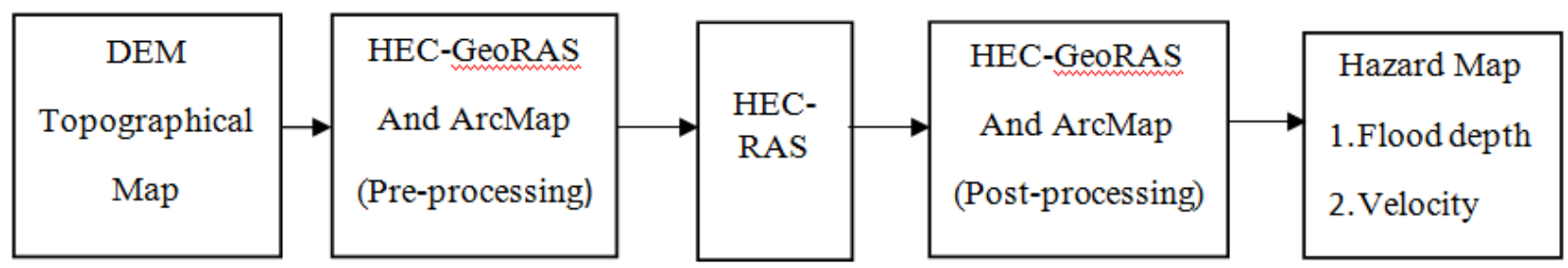

Figure 2: Flow chart for river flood modelling

\subsection{Flood Inundation Map for River Zungur}

The simplest way to map flood inundation is by flow simulation models coupled with DEM data. The only essential dataset required for HEC-GeoRAS is the terrain data. The DEM was processed to create the TIN. The river cross sections, stream centerlines, stream bank lines, flow lines, and other river geometry information were extracted from the TIN for the HECGeoRAS model. After the RAS geometry data preparation, the HEC-GeoRAS model was used to generate the RAS GIS import file that can be used as input in the HEC-RAS model.

In the HEC-RAS model, the cross-sections were checked, the river geometry was edited and the Manning's coefficient was inputted. The analyzed discharge data and boundary conditions were also inputted inside the model. The water surface level for each return period was exported to HEC-GeoRAS for final inundation mapping along the river. Figure 2 shows the schematic diagram of the river flood modelling.

\section{RESULTS AND DISCUSSIONS}

Frequency analysis was carried out using rainfall data of 60 years (1949-2009). Log Pearson Type III and Gumbel distribution method were compared; the two selected probability distribution models were plotted on the probability-probability (P-P) plot and subjected to three tests of goodness of fit. From Figure 3 and Table 2, it is evident that the log-Pearson type III distribution corresponds closer to the reference linear line than the Gumbel distribution. The distribution has the lowest test statistic and is therefore ranked first [10] (Table 2). Therefore, log-Pearson type III distribution is the most suitable for the watershed.
Similar researches carried out in other parts of Nigeria indicated that log-Pearson type III has the highest score and is therefore the best-fit probability distribution [11-12].

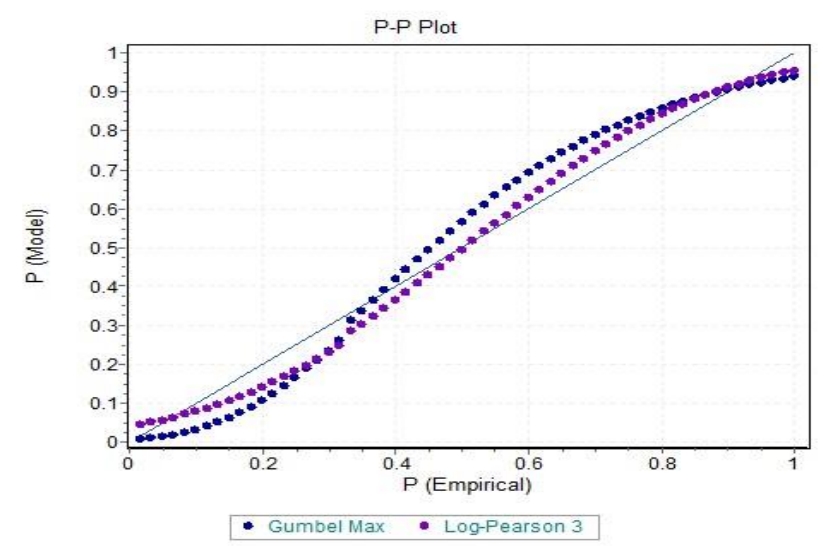

Figure 3: Probability-Probability (P-P) Plots for the selected distribution models.

The annual maximum discharges for flood of return periods of 2, 5, 10, 25, 50 and 100 years were calculated and presented in Table 3 using the rationale formula as shown in Equation 1.

$$
\mathrm{Q}=\mathrm{CIA}
$$

where $\mathrm{C}$ is runoff coefficient $=0.5$ for rolling cultivated area. A is surface area of the catchment $=8266 \mathrm{~km}^{2}$. I $(\mathrm{mm} / \mathrm{hr})$ is rainfall intensity which was calculated according to Equation 2 [13].

$$
I=\frac{a T^{b}}{(t+c)^{d}}
$$

where $\mathrm{T}$ is the return period, $\mathrm{t}$ is time of concentration of the catchment $=192$ minutes and a,b,c and $d$ are non- negative coefficients with values of 2208, 0.17, 6 and 2.2 respectively for Bauchi [13].

Table 2: Results of the Goodness of Fit Test for the selected probability distribution models

\begin{tabular}{llllllll}
\hline \multirow{2}{*}{ S/N } & \multirow{2}{*}{ Distribution } & \multicolumn{2}{l}{ Kolmogorov Smirnov } & \multicolumn{2}{l}{ Anderson Darling } & \multicolumn{2}{l}{ Chi-Squared } \\
\cline { 3 - 7 } & & Statistics & Rank & Statistics & Rank & Statistics & Rank \\
\hline 1 & Log-Pearson Type III & 0.07025 & $1^{\text {st }}$ & 0.66721 & $1^{\text {st }}$ & 2.8696 & $1^{\text {st }}$ \\
2 & Gumbel & 0.10939 & $2^{\text {nd }}$ & 1.9729 & $2^{\text {nd }}$ & 8.0199 & $2^{\text {nd }}$ \\
\hline
\end{tabular}


Table 3: Flood frequency analysis of Zungur River for 192 minutes duration

\begin{tabular}{llll}
\hline Return Period (years) & Rainfall depth $(\mathrm{mm})$ & Intensity $(\mathrm{mm} / \mathrm{hr})$ & Peak Discharge $\left(\mathrm{m}^{3} / \mathrm{s}\right)$ \\
\hline 2 & 60.36 & 18.86 & 21669 \\
5 & 70.56 & 22.05 & 25334 \\
10 & 79.41 & 24.82 & 28517 \\
25 & 92.83 & 29.01 & 33332 \\
50 & 104.46 & 32.64 & 37502 \\
100 & 117.56 & 36.74 & 42213 \\
\hline
\end{tabular}

The result of flood frequency analysis was used as steady flow data for simulation in the HEC-RAS model. The critical depth of upstream and downstream was considered as boundary condition and Manning's $n$ value was also used in the analysis. The HEC-RAS model was exported to the HEC-GeoRAS environment for the generation of the area extent, flood depth and flood velocity map.

The results from the analysis shows that there is a correlation between the discharge, probability of occurrence, flood inundation depth and the area extent of inundation, in that increasing return period and the corresponding discharge resulted in increases depth of inundation and area of inundation. Generally, the difference of inundated areas between the lowest magnitude and highest magnitude flood was not too significant. From Table 4, the flood inundation simulation showed that at a return period of 2-years, the maximum depth was $5.37 \mathrm{~m}$ and affected area is $186.71 \mathrm{~km}^{2}$ of the watershed and the maximum depth and flooded area respectively increased to $7.37 \mathrm{~m}$ and $205.32 \mathrm{~km}^{2}$ in the case of 100-years return period.
Table 4: Area and depth of inundation at different return periods

\begin{tabular}{|c|c|c|}
\hline $\begin{array}{ll}\text { Return } & \text { Period } \\
\text { (years) } & \end{array}$ & $\begin{array}{l}\text { Area Inundated } \\
\left(\mathrm{km}^{2}\right)\end{array}$ & $\begin{array}{l}\text { Depth of } \\
\text { Inundation (m) }\end{array}$ \\
\hline 2 & 186.71 & $0-5.37$ \\
\hline 5 & 189.15 & $0-5.75$ \\
\hline 10 & 193.59 & $0-6.06$ \\
\hline 25 & 197.63 & $0-6.56$ \\
\hline 50 & 200.09 & $0-6.88$ \\
\hline 100 & 205.32 & $0-7.37$ \\
\hline
\end{tabular}

Figure 4 show floodplain mapping based on the depth and velocity for 100 years flood event. It is indicated that for 100 years return period, the flood velocity ranges from $0-7.37 \mathrm{~m} / \mathrm{s}$. Areas along the river channel have the highest flow velocity. All areas at the left and right over bank of the river channel have flow velocity greater than $2 \mathrm{~m} / \mathrm{s}$ which are classified as high hazard which means that there may be probable washing away of agricultural crops and even loss of life due to the high velocity flow. This high velocity flow can also result in scouring around the culverts and bridge within the floodplain.

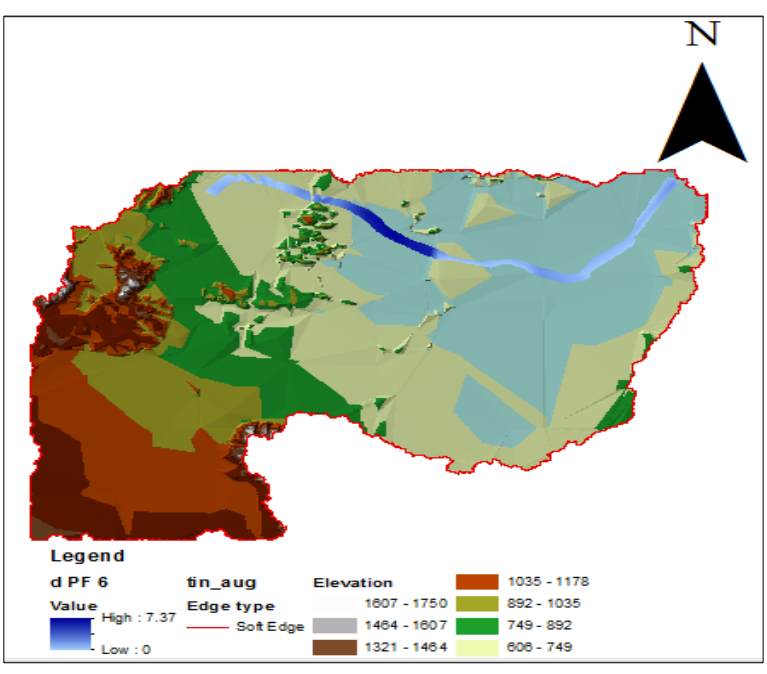

a)Flood depth map

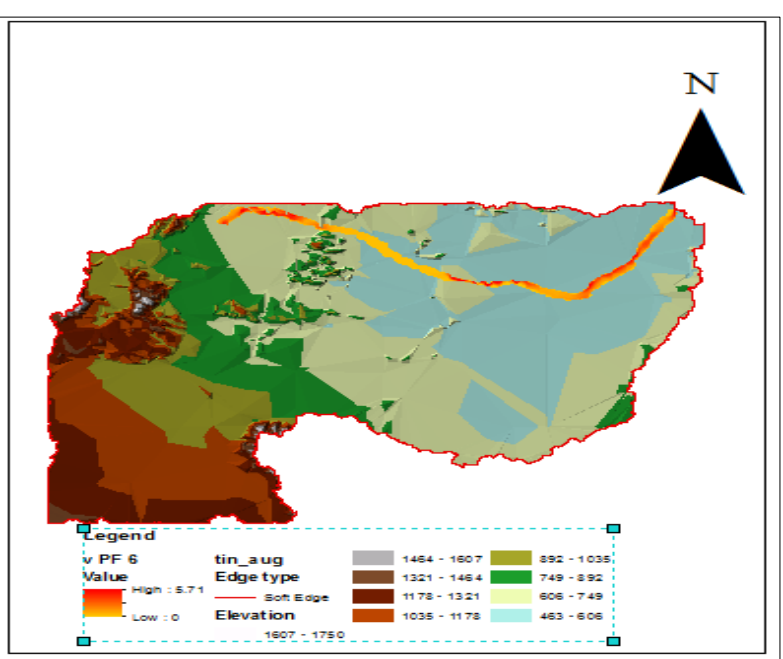

b) Velocity map

Figure 4: Flood depth and velocity map for 100 years return period 


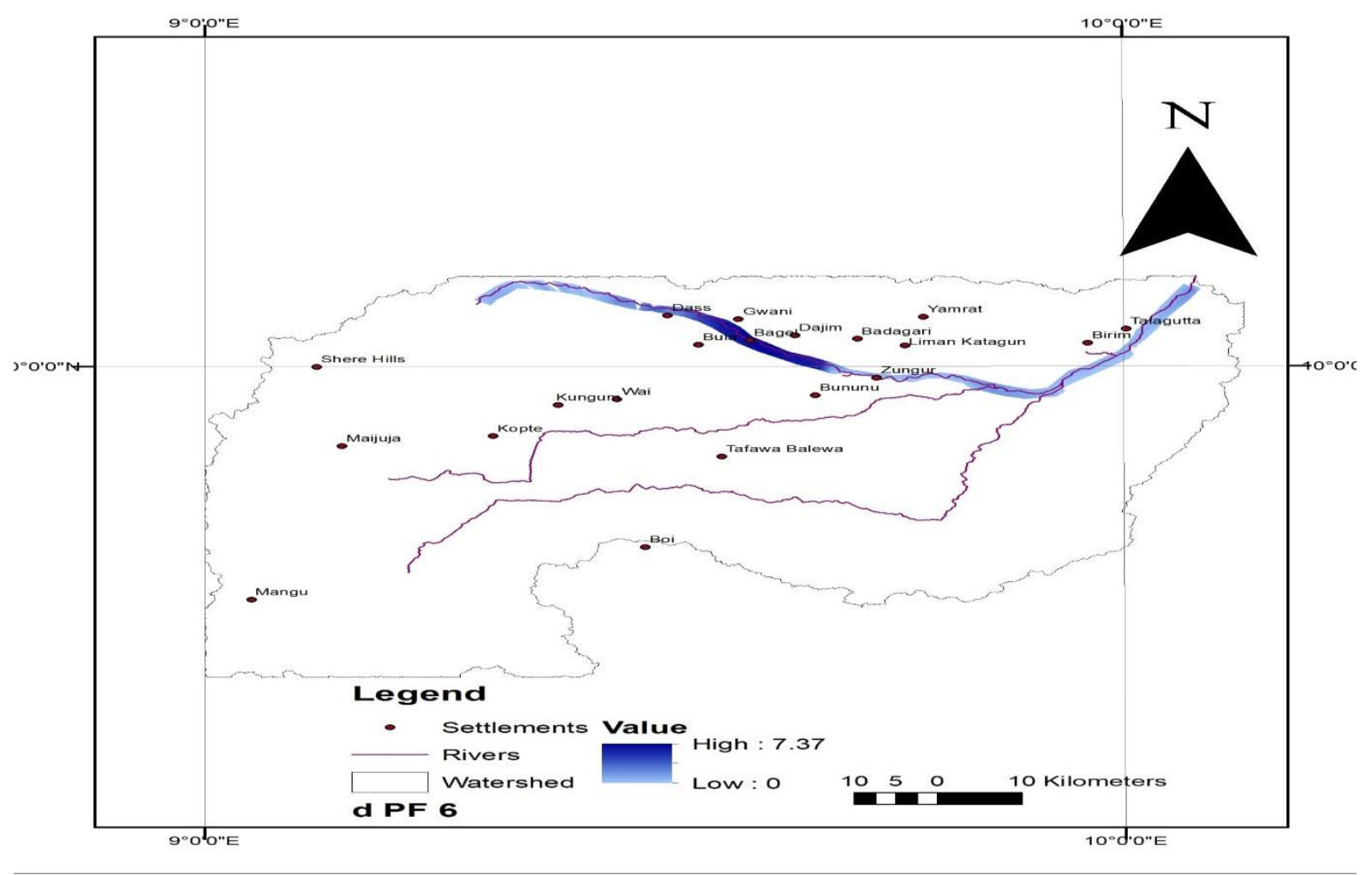

Figure 5: Settlements at risk of 100 years flood

From Figure 5, following the flood analysis and overlay operation, eight settlements were seen to be at risk by the 100 year flood from the settlement map. These places namely are: Zungur, Bagel, Dass, Sabongida, Mun, Talagutta, Gwani and Birim. Out of these settlements, Zungur, Bagel and Dass are more at risk than other settlements as they are closer to the river channel. The Land Use map generated shows that agricultural areas occupies the highest percentage of land that are close to the floodplain which shows that agricultural land are the most affected areas by flood from 2-year to 100-year floods events.

\section{CONCLUSIONS}

The study used steady flow hydraulic model and GIS in the preparation of hazard maps. The major tools models used is the one-dimensional HEC-RAS and ArcMap GIS for spatial data processing and HECGeoRAS for interfacing between HEC-RAS and ArcView GIS. DEM and rainfall data have been used for inundation mapping. The result would have been different if stream flow data were used. For 100 years return period, inundation area was estimated to be $205.32 \mathrm{~km}^{2}$ with a corresponding discharge of 42213 $\mathrm{m}^{3} / \mathrm{sec}$ and inundation depth ranging from $0-7.37 \mathrm{~m}$. Output of the study shows that most affected activity within the floodplain is agriculture and eight settlements within the catchment are likely to be affected. The use of flow simulation models coupled with DEM data present an effective approach to flood inundation modelling. These softwares have been effective in mapping out of critical areas where flooding will occur within the Zungur River Basin. It is recommended that harvest of rainy season crops within the flood plain should be completed before end of July and the medium and high hazard areas should only be used for dry season farming. Small scattered settlements within the floodplain, in Zungur and other areas should be cautioned on the dangers of living in such areas and possibly evacuated and resettled in a safer location. For modelling flows in overbanks, topographic data should be of high resolution so that the topography of the floodplains could be properly represented.

\section{REFERENCES}

[1] Bikram, M..Flood Plain Analysis and Risk Assessment of Lothar Khola, AnUnpublished Master Thesis in Tribhuvan University Institute of Forestry Pokhara Nepal. 2010

[2] Drogue, G., Pfister, L., Leviandier T., Idrissi A., Iffly J.F., Matgen P., Humbert J., and Hoffmann L. "Simulating the spatial temporal variability of stream flow response to climatic change scenarios in a mesoscale basin". Journal of Hydrology, Vol.293, 2004 pp 255-269. 
[3] Etuonovbe, A K. "The devastating effect of flooding in Nigeria", FIG Working Week 2011, bridging the Gap between Cultures, Marrakech, Morocco, available at http://www.fig.net/pub/fig2011/ papers/ts06j/ts06jetuonovbe 5002 .pdf. Accessed November 11, 2013.

[4] Nicholas, J. E. Assessment of the 2013 flooding in Mararaba Karu Local Government area of Nasarawa State. An Unpublished Master Thesis. Department of Geography and Remote Sensing, Ahmadu Bello University, Zaria. 2014.

[5] Tokunbo, A. and Ezigbo. Floods Claims 363 Lives, Displaced 2.1 Million People Says NEMA.THISDAY. Retrieved from http://Allafrican.com, 2012

[6] Narath, N. and Vichiam, P. "Flood plain mapping using HEC-RAS and GIS in Nam Phong River Basin, Thailand". Intern. J. of Env. and Rural Devt, Vol. 6, Number 1, 2015, pp 153-158.

[7] Bashir, A., Muhammed S.K., Mohsin J.B., and Zakir H.D. "Hydrological modelling and flood hazard mapping of Nullah Lai". Proc. Pakistan Acad. Sciience Vol 47, Number 4, 2010, pp 215-226.

[8] Sadrolashrafi, S. S., Thamer A. M., Ahmad R. B. M., Majid K. K., and Amir S. "Integrated modeling for flood hazard mapping using watershed modeling system". American Journal of Engineering and Applied Sciiences Vol. 1, 2008, pp 149-156.

[9] USACE, Hydrologic Engineering Center, RiverAnalysis System HEC-RAS, Hydraulic Reference Manual Version 3.0, January, 2001. www.usace.army.mil.

[10] MathWave Technologies U.S.A., EasyFit Professional Software Version 5.6, 2015.

[11] Olonfintoye, O.O., Sule, B.F. and Salami, A.W. "Best-fit probability distribution model for peak daily rainfall of selected Cities in Nigeria". New York Science Journal Vol. 2, Number 3, 2009, pp 1-12.

[12] Izinyon, O.C. and Ajumuka, H.N. "Evaluation of some flood prediction models for three flow gauging stations in upper Benue river basin in Nigeria - part 1" Nigerian Journal of Technology. Vol. 32, Number 2, 2013, pp 184-196.

[13] Sule, B.F and Ige, T. "Synthesis of Isopluvial Maps for Nigeria using IDF Equations Derived from daily Rainfall Data". Journal of Scientific and Engineering Research, Vol 3, Number 3, 2016, pp. 505-514. 